\title{
TAXPAYER CRITERION AS A GROUND FOR RECOGNIZING A LOCAL TAX RESIDENT AND VOTER AT LOCAL ELECTIONS
}

\section{Nataliia Iakymchuk}

\section{INTRODUCTION}

The establishment of suffrage as a legal institution has come a long way, driven by the formation and development of legal doctrine, the history of the emergence of the principles and mechanisms of democracy in Europe, the recognition of universal suffrage and the consolidation of that principle and its guarantees at the international level.

The focus of the researchers is both the state of recognition and consolidation in law of all elements of suffrage, as well as the analysis of enforcement, those technical and bureaucratic barriers that do not allow a person to fully establish their rights in the electoral process.

Some issues of participation of citizens - internally displaced persons and foreigners in local elections in EU countries in Ukraine were investigated by M.M. Antonovich, V.I. Ivancho, A.V. Levenets, E.V. Tkachenko, O.V. Chernetska, and other scientists. However, such a circumstance as having by resident resident tax status with a fixed tax address, as well as a voter in local elections, which characterize their financial and political connection not only with the state but also with the relevant territorial community (municipality, commune, etc.)), remains mainly out of the researcher's attention.

\section{The emergence of the phenomenon of "tax exemptions" and refusal to recognize it at the constitutional level of universal suffrage}

The use of a wide range of electoral qualifications was characteristic of the period of "censorship democracy" prior to the constitutional implementation of the principle of universal suffrage, not limited by property (tax) qualification, the emergence of which is associated with the emergence of electoral law and the propagation of electoral theory, co-authored by the famous French politician B. Constant de Rebecque. According to this theory, only those individuals who have material well-being and proper education could be involved in the elections, which, in particular, provides them with freedom and independence in making the choice ${ }^{1}$.

\footnotetext{
${ }^{1}$ Shapoval V.M. (2005) Suchasniy konstitutsionalizm : monogr. [Modern Constitutionalism: monogr.], Kiev: Salkom. p. 319 [in Ukrainian]
} 
The electoral qualification (Latin census - valuation; property) is defined as a condition established by law for obtaining and exercising a suffrage by a citizen (active or passive). In the world practice, the most common was the property qualification (the need to own a set minimum of ownership) and the associated tax qualification.

Thus, in the Netherlands, the electoral law established by the Constitutions of 1798 and 1848 was burdened with a rather high tax standard. It was first abolished by the Constitution of 1887 and later by the laws of the 1990s.

In the United States, when the Constitution was adopted in 1787, all thirteen states had an economic qualification to vote: ten provided for ownership of property and three required tax payments. At the same time, the eligibility requirements were greatly reduced. For example, in Rhode Island, men who took the Oath of Freeman - acquired the right to vote if they owned real estate worth 40 pound sterlings or rented for 40 shillings a year; and in 1800, tax certification was commonplace and only three states (Kentucky, New Hampshire and Vermont) imposed universal suffrage, but only for white men. By 1830 , ten states had introduced universal suffrage without property or tax qualifications, but the other eight states restricted voting by taxpayers and a property qualification was imposed in six. In 1860, only five states retained the tax qualification and two states property ${ }^{2}$. Only in 1964, the 24th Amendment to the US Constitution was adopted, which prohibits states from depriving any citizen of the right to vote in certain elections, "as a result of non-payment of any poll tax or other tax". Since then, confirmation of permanent or temporary residence determines whether a person has the right to vote.

According to the Sardinian Constitution of 1848, the provisions of which later extended to the entire Italian kingdom, the right to vote belonged only to citizens who were twenty-five years of age and paid a tax of 40 francs $^{3}$.

In 1973, property and tax standards were imposed in Austria, and elections were held on curia, which limited the number of voters. Since 1896, the tax requirement has decreased, but only men who paid 8 korunas in direct taxes had the right to vote.

In France in 1791, only 16 percent of the adult population were eligible to vote. After the adoption of the Constitution in 1791, the property qualification was increased and the proportion of those eligible to participate in the elections was reduced to 8 percent, with the elections being indirect and two-

${ }^{2}$ Carol Berkin The Evolution of Voting Rights (2018). The Gilder Lehrman Institute of American history. www.gilderlehrman.org. Retrieved from https://www.gilderlehrman.org/ history-by-era/government-and-civics/essays/winning-vote-history-voting-rights

${ }^{3}$ Istoriya XIX veka. Konets veka, 1870-1900. (1939) Chast' 1. [History: The Nineteenth Century. End of the Century, 1870-1900. Part 1] / ed. E. Lavisse, A. Pambaud, E. Tarle. Moscow: State Economic and Social Publishing, p. 291. [in Russian]. 
stage. In 1817 , the election became direct, and the property qualification was set at 300 francs of direct tax (such a tax was paid by only 0.3 percent of the adult population of the country). The revolution in France in 1830 brought the reduction of property qualifications for the use of active suffrage up to 200 francs of direct tax. It was only as a result of the revolution of 1848 that universal suffrage was proclaimed in France, but since women and some other categories of citizens were not eligible to participate in the elections, no more than one third of the population could participate in the elections.

The tax requirement was also established by the Belgian Constitution in 1831 and was also quite high, in particular, 35-year-old men who were both homeowners and paid 1000 florins of direct tax held an active suffrage, and men of 25 years who paid a tax minimum of 20 florins; however, in different provinces the own size could be set. Only a wealthy taxpayer could be elected.

In Japan, on the basis of the Constitution of 1889, a sufficiently high tax standard was established. As a result, in the early twentieth century approximately 3 percent of the country's population were granted with voting rights.

Thus, at the beginning of the First World War, direct property and tax qualifications for active suffrage were maintained in several countries.

In the modern period, in some countries the tax qualification remains, but in a truncated form. In particular, regarding active suffrage, Article 29 (1) of the Constitution of the Kingdom of Denmark states: “... the law establishes in which cases criminal penalties and social assistance for poverty may be legitimate grounds for deprivation of suffrage." As a result, in some municipalities, persons who did not pay the municipal tax in time are not entered in the voter register. Other times, in some municipalities, persons who receive poverty relief or bankruptcy do not have the right to vote ${ }^{4}$. However, in individual states (Argentina, Norway, Canada), the tax qualification has been maintained solely with respect to passive suffrage ${ }^{5}$.

Instead, in the twentieth century, at the constitutional and international levels, the principle of universal suffrage was adopted, which did not provide for the possibility for states to establish an economic qualification (property or

\footnotetext{
4 Daniya: analiz izbiratel'nogo zakonodatel'stva $\mathrm{V}$ kontekste soblyudeniya obshchedemokraticheskikh standartov i prav cheloveka. (2009) [Denmark: analysis of electoral law in the context of observance of democratic standards and human rights.] Sait of CIS-Europe Monitoring Organization. venice.coe.int. Retrieved from http://www.cis-emo.net/ru/ materials/demokraticheskie-processy/daniya-analiz-izbiratelnogo-zakonodatelstva-v-kontekstesoblyudeniya-obshchedemokraticheskih [in Russian].

${ }^{5}$ Martselyak, O.V., Martselyak, S.M. (2015) Pravova pryroda y vydy tsenziv u vyborchomu pravi [Legal nature and types of qualifications in electoral law]. Konstytutsiyno-pravovi akademichni studiyi [Constitutional Law Academic Studies.], № 2, p. 110. [in Ukrainian].
} 
tax) and to promote the continued development of a set of electoral rights guarantees.

In the first stage of affirmation of the principle of universal suffrage in the world, voter status was generally recognized by citizens, but for local elections, voters were recognized by citizens according to their official place of residence. Almost all modern constitutions contain the provision that citizens have the right to vote. In particular, Article 70 of the Constitution of Ukraine establishes that citizens of Ukraine who have reached the age of eighteen have the right to vote in elections and referendums.

In the second stage, universal suffrage was recognized by citizens who, in the event of changing their actual place of residence, could declare their desire to participate in local (municipal elections) at their address.

\section{Establishing in the law of relationship between the tax address and the electoral address}

The constitution of Ukraine and international human rights standards clearly define the universality and equality of the rights of all citizens, in particular in matters of suffrage.

Important European standards for suffrage include the provisions of Article 3 of Protocol No. 1 (1952) to the The European Convention on Human Rights, which establishes the right to free elections and states: "The High Contracting Parties undertake to hold free elections at reasonable intervals by secret ballot, under conditions which will ensure the free expression of the opinion of the people in the choice of the legislature" $"$. Article 14 of the Convention prohibits discrimination on any ground such as sex, race, colour, language, religion, political or other opinion, national or social origin, association with a national minority, property, birth or other status ${ }^{7}$.

${ }^{6}$ Lenher Ya.I. (2016) Vyborchi prava vnutrishn'operemishchenykh osib v Ukrayini: koliziyni pytannya ta mozhlyvi shlyakhy yikh usunennya. [Voting Rights of Internally Displaced Persons in Ukraine: Conflict Issues and Possible Remedies]. Konstytutsiyno-pravovi akademichni studiyi [Constitutional Law Academic Studies], № 1, pp. 19-25 [in Ukrainian].

${ }^{7}$ Frants Macher (2004) Dopovid' pro skasuvannya obmezhen' prava holosu na zahal'nykh vyborakh, skhvalena Venetsians'koyu Komisiyeyu (Venetsiya, 3-4 hrudnya 2004 r.). [Franz Macher Report on the Abolition of Restrictions on the Right to Vote in the General Election of, approved by the Venice Commission (Venice, 3-4 December 2004).] Yevropeys'kyy demokratychnyy dorobok $u$ haluzi vyborchoho prava: Materialy Venetsians'koï Komisiï, Parlaments'koï Asambleï, Komitetu Ministriv, Konhresu mistsevykh i rehional'nykh vlad Rady Yevropy: per. $z$ anhl. / za red. Yu. Klyuchkovs'koho. [European democratic achievements in the field of suffrage : Proceedings of the Venice Commission, Parliamentary Assembly, Committee of Ministers, Congress of Local and Regional Authorities of the Council of Europe: trans. from English. / per row Y. Klyuchkovsky, Vyd. 2-e, vypr. i dopovn]. K., P. 140 [in Ukrainian] . C. 140. 
At the same time, the citizenship requirement for the right to vote or to be elected has never been challenged in court decisions, and the requirement of a certain period of residence has also been found admissible (Polacco and Garofalo / I, 1997).

The European Court of Human Rights has consistently emphasized that there is scope for natural restrictions within the scope of Article 3 of Protocol No. 1 and that States enjoy a wide margin of appreciation, of course, under the control of the Court.

However, measures taken by States should not infringe the very nature of the rights protected by Article 3 of Protocol No. 1. The measures under consideration should have a legitimate aim and not be arbitrary or disproportionate.

It is possible to conclude from the above recent judgments (Labita / I, 2002; Zadenoka / LV, 2004; Hirst / GB, 2004) that the Court is inclined to agree to restrictions only if they have a strong basis.

Thus, paragraph 9 of the Council of Europe Committee of Ministers' Recommendations of the Committee of Ministers to member states on internally displaced persons (2006) stipulates that Member states should take appropriate legal and practical measures to enable internally displaced persons to effectively exercise their right to vote in national, regional or local elections and to ensure that this right is not infringed by obstacles of a practical nature ${ }^{8}$.

Council of Europe Parliamentary Assembly Recommendation 1877 (2009) draws the attention of States to the need to ensure that "internally displaced persons can exercise their right to participate in public affairs at all levels, including their right to vote or stand for election, which may require special measures such as IDP voter registration drives, or absentee ballots (para. 15.3.12) ${ }^{9}$.

It should be noted that the development of the electoral law of Ukraine is at a specified stage, namely, the right to change the place of the election address, according to the voter's application, is being put into practice. Today, a motivated request of a voter to change the voting place of a citizen who has the right to vote in the relevant election or referendum can be carried out in the cases provided for in Art. 7 and 20 of the Law of Ukraine "On the State Voter Register" and Article 8 of the Law of Ukraine "On Ensuring the Rights and Freedoms of Internally Displaced Persons". However, these provisions

\footnotetext{
${ }^{8}$ Recommendation $\operatorname{Rec}(2006) 6$ of the Committee of Ministers to member states on internally Recommendation $\operatorname{Rec}(2006) 6$ of the Committee of Ministers to member states on internally displaced persons. rm.coe.int. Retrieved from https://rm.coe.int/16806b5aaf

9 Recommendation 1877 (2009) Parliamentary Assembly "Europe's forgotten people: protecting the human rights of long-term displaced persons". rm.coe.int. Retrieved from http://assembly.coe.int/nw/xml/XRef/Xref-XML2HTML-EN.asp?fileid=17759\&lang=en
} 
have not been reproduced in the provisions of the Law of Ukraine "On Local Elections".

However, Article 3 of the above-mentioned Law states that the right to vote in elections of deputies of a village, settlement, city council, election of a village, settlement, city mayor shall have citizens of Ukraine who have the right to vote under Article 70 of the Constitution of Ukraine, who belong to the respective territorial community and reside within the relevant constituency. Therefore, the criterion defines the belonging to the territorial community, which can be first of all confirmed by the fact that the person has defined the administrative-territorial point of the respective territorial community with his tax address.

\section{Dependence of the voter's legal status at local elections on recognition by the person of the status of the local tax resident according to the law of EU and Ukraine}

In the third historic phase, which began in the middle of the last century, universal suffrage was also recognized by foreigners, first and foremost EU nationals within the EU, and later by non-EU citizens who reside on a permanent basis or (and) are tax residents.

The right of EU citizens to vote and stand in local and European Parliament elections in their own countries is one of the aspects of European integration processes. Most EU countries have already introduced the electoral rights of foreigners in national law. In Belgium and Portugal, even citizens of Ukraine who live there have the right to choose local authorities.

Local elections can be a different matter. Eleven states have statutes that permit nonresidents, such as second-home owners or business owners, to vote in local, municipal, and/or special district elections such as irrigation, water, sewer and conservancy districts. There are: 1) three states allow nonresident voting in municipal or town elections: Connecticut, Delaware, New Mexico; 2 ) ten states allow nonresident voting in certain special district elections. New Mexico and Delaware have provisions allowing nonresidents to vote in special district elections in addition to municipal elections: Arizona, Arkansas, California, Colorado, Delaware, Nebraska, New Mexico, Oregon, Tennessee, Wyoming ${ }^{10}$.

In recent years, property owners across the country have called for the extension of suffrage for non-residents. Relying on John Adams' argument, they claim that their economic interest in a particular community gives them the right

${ }^{10}$ Voting by Nonresidents. (2018) The Gilder Lehrman Institute of American History. 6.20.2018. Retrieved from http://www.ncsl.org/research/elections-and-campaigns/non-residentand-non-citizen-voting.aspx 
to speak in local affairs. Attempts have been made to counter this trend. For example, in Del, Connecticut, residents of the city have come to court over this issue, claiming that non-residents are diluting their voting authority. The court held that the statute had a "sound basis" for the extension of suffrage to nonresidents and was thus decided in favor of the property owners.

Since then, the impulse has increased in other places. In 1995, this movement was the most diverse, and the resort town of Mountain Village, Colorado has approved a statute that allows non-residents to vote if they own at least 50 percent of the ownership of the local property.

One of the important international instruments enshrining the electoral rights of non-citizens is the Council of Europe Convention on the Participation of Foreigners in Public Life at Local Level, which has been ratified by only nine states, including Denmark, Finland, the Netherlands, Norway and Sweden, but Ukraine is now among the Council of Europe member states that have not yet ratified the Convention. In particular, Art. 6 of the Convention states that "Each Party undertakes, subject to the provisions of Article 9, paragraph 1 (concerning permissible restrictions during a war or other state of emergency in the country which threatens the life of the nation), to grant to every foreign resident the right to vote and to stand for election in local authority elections, provided that he fulfils the same legal requirements as apply to nationals and furthermore has been a lawful and habitual resident in the State concerned for the 5 years preceding the elections. However, a Contracting State may declare, when depositing its instrument of ratification, acceptance, approval or accession, that it intends to confine the application of paragraph 1 to the right to vote only" 11 .

According to Venice Commission's Code of Good Practice in Electoral Matters $\left.^{12}: 1\right)$ universal suffrage means in principle that all human beings have the right to vote and to stand for election; 2) This right may, however, and indeed should, be subject to certain conditions, which include residence: that is, the state may require residence, while it is recommended to allow foreigners who reside in the locality for a longer period to participate in local elections (CDL-AD (2004) 040, para. 9). A similar recommendation of the Parliamentary Assembly also applies to the participation of foreigners in local referendums (Recommendation 1704 (2005), paragraph 13.vi.c). However, some member states of the Council of Europe have not yet implemented a general recommendation, which of course requires some administrative effort.

\footnotetext{
${ }^{11}$ Convention on the Participation of Foreigners in Public Life at Local Level. Strasbourg, Council of Europe 5.II.1992. rm.coe.int. Retrieved from https://rm.coe.int/168007bd26

${ }^{12}$ Guidelines on Elections. Adopted by the Venice Commission at its 51st Plenary Session (Venice, 5-6 July 2002). venice.coe.int. Retrieved from https://www.venice.coe.int/webforms/ documents/CDL-AD(2002)013-e.aspx
} 
Thus, Member States should pursue policies that are consistent with the Council of Europe's goals, but there is no legal obligation to follow ideas stemming from the various legally non-binding instruments (resolutions, recommendations) of the Council of Europe institutions, including the Code of Good Practice in Electoral Matters (Venice Commission document of July 2003). The same applies to the 1992 Convention on the Participation of Foreigners in Public Life at Local Level, until it has been ratified.

The right of participation of foreigners and stateless persons in elections is enshrined in the sources of European Union law, in particular Article 19 of the Treaty establishing the European Community, in Art. 10 (former Article 8a) of the Treaty on European Union, which provides that "Every citizen shall have the right to participate in the democratic life of the Union. Decisions shall be taken as openly and as closely as possible to the citizen"13. In Art. 8b of Part Two of the Treaty on Nationality states that "every citizen of the Union residing in a Member State of which he is not a national shall have the right to vote and to stand as a candidate at municipal elections in the Member State in which he resides, under the same conditions as nationals of that State" ${ }^{\text {.14 }}$. Most Member States have enshrined in national law the suffrage of EU citizens who do not have the nationality of their country of residence, both in elections to the EU Parliament and in local elections, but in some cases EU countries, in particular, Bulgaria and Latvia have not yet fully implemented these rules. So, "ODIHR expressed respective concerns in Bulgaria where resident foreigners were not granted right to vote in local elections. A recommendation was also made in Latvia to grant non-citizens a right to vote in local elections" $" 15$.

Detailed measures for the exercise of the right to vote and to nominate candidates for municipal elections are laid down in Council Directive 94/80/EC, which states that the right to vote and to participate in the elections of candidates for municipal elections in the Member State of residence contained in Article 8b (1) of The Treaty establishing the European Community is an example of the application of the principle of equality and unlawfulness, discrimination between citizens and non-citizens and the

${ }^{13}$ Treaty on European Union (Maastricht, 7 February 1992) - Consolidated version 2007. www.cvce.eu. Retrieved from https://www.cvce.eu/en/obj/treaty_on_european_union_maastricht_ 7_february_1992_consolidated_version_2007-en-e92737d6-7557-4ea1-9ca5-123368a7fb88.html

${ }^{14}$ Treaty establishing the European Community - part two: citizenship of the Union - article $8 \mathrm{~b} / *$ Codified version of the treaty establishing the European Community. Official Journal. eur-lex.europa.eu. p. 224, 31/08/1992 p. 0011. Retrieved from http://eur-lex.europa.eu/legalcontent/RO/TXT/?uri=CELEX:11992E008B

${ }^{15}$ Review of Electoral legislation and Practice in OSCE participating states. OSCE, Office for Democratic Institutions and Human Rights (Warsaw, October 15, 2013). www.osce.org. Retrieved from www.osce.org/odihr/elections/107073?download=true 
consequence of the right of free movement and residence enshrined in Article 8a of this Treaty.

Any derogation from the general rules of this Directive must be justified, in accordance with Article 8b (1) of the Treaty, by problems specific to the Member State; given that any deviation should, by its nature, be revised. Directive 94/80 / EC states that such specific problems may arise in a Member State in which the proportion of Union citizens of the voting age, who reside in it but are not citizens of it, is very much above the average. Such a circumstance is justified when such citizens make up more than $20 \%$ of the total number of voters; however, such derogations from a Member State should be based on residence criteria ${ }^{16}$.

Regarding the participation in local and regional elections, if the stipulated period of residence does not exceed several months, the residence requirement does not seem to be contrary to the principle of universal suffrage; the establishment of a longer term is permissible only for the protection of national minorities (decision of the European Commission on Human Rights No 23450/94 of 15.09.97 in the case of Polacco and Garofalo v. Italy (concerning Trentino-Alto Adige)).

It is important to note that the Venice Commission Interpretation Directive states that states may "Registration could take place where a voter has his or her secondary residence, if he or she resides there regularly and it appears, for example, on local tax payments; the voter must not then of course be registered where he or she has his or her principal residence"17. It is clear that in this case, voter registration at the main residence is not allowed.

We would like to emphasize that the fact of voter recognition of the taxpayer to the local budget, at the expense of which the functions are performed and the tasks of local self-government are accomplished, is a fact of belonging of the person to the territorial community, his/her financial participation in joint solving of problems of the residents of the respective administrative-territorial unit.

Recognition of a person as a tax resident, and especially a regional tax resident whose tax address does not correspond to the official place of registration - is, in our opinion, sufficient reason for recognizing the person as

${ }^{16}$ Council Directive 94/80/EC of 19 December 1994 laying down detailed arrangements for the exercise of the right to vote and to stand as a candidate in municipal elections by citizens of the Union residing in a Member State of which they are not nationals. eur-lex.europa.eu. Retrieved from http://eur-lex.europa.eu/legal-content/EN/TXT/HTML/?uri=CELEX:31994 L0080\&from $=\mathrm{EN}$

${ }^{17}$ Explanatory report adopted by the Venice Commission at its 52nd Plenary Session (Venice, 18-19 October 2002). Europian commission for democracy through law (Venice commisson). www.venice.coe.int. CDL-AD(2002)023rev2-cor. p. 14. Retrieved from https://www.venice.coe.int/ webforms/documents/default.aspx?pdffile=CDL-AD(2002)023rev2-cor-e 
a member of the territorial community. In this case, the polling address must match the voter's tax address.

Paragraph 5 of Council of Europe Parliamentary Assembly Resolution 1459 (2005) on the abolition of restrictions on voting rights of 24 June 2005 states that all legal residents are normally obliged to pay local taxes and their lives are directly affected by the decisions of local authorities. The right to vote and to stand as candidates in local elections should therefore be granted to all legal residents having lived long enough in the country, regardless of their nationality or ethnic origin. In this context, the Assembly urges the countries concerned to implement the recommendations by the Council of Europe Commissioner for Human Rights on granting that right to residents with the special status of "non-citizens", in accordance with the Convention on the Participation of Foreigners in Public Life at Local Level.

Residents are accounted for as taxpayers in state registers that are separate from the voter register or combined into a single state register. Voter registration can be either automatic or by application, which is relevant for citizens of the state who belong to the circle of internally displaced persons, as well as for non-citizen residents, if the voter register and the register of taxpayers are not combined in a single state register. However, in individual states, people must register before they can vote or stand as a candidate in an election, which is seen not as a restriction on universal suffrage, but as a component of the way it is exercised.

Directive 94/80/EC provides that Member States, where voting is optional, may adopt an automatic voter registration system. This is already happening in Austria (except Burgenland), Denmark, Estonia, Finland, Germany, Hungary, Latvia, Lithuania, Malta, the Netherlands, Romania, Slovakia, Slovenia and Sweden, Chile and several other countries. Such practices will not create an additional burden for citizens who wish to exercise their right to vote, since they are not required to submit a new application for registration during the imperative restriction.

Typically, voter registries are updated using a variety of sources, including tax authorities. Thus, in Canada it is the Canadian Revenue Agency, in Denmark it is the National Register used for tax and election lists kept by the Ministry of Welfare (Velfærdsministeriet). In Finland, a change of address in the register is automatically registered by all other public authorities (eg local tax authority, social security authorities, etc.). In Norway, a national register (Folkeregisteret,) is used for tax lists, voter lists, membership of a unified health care system and other purposes, and is maintained by the tax authorities ${ }^{18}$.

${ }^{18}$ Yevropeys'kyy vyborchyy dorobok [European Electoral Achievement]. CDL (2002) 7 rev (f). www.venice.coe.int. Retrieved from https://www.venice.coe.int/files/CDL-elec-opinionsUKR.pdf [in Ukrainian]. 
Ukraine also provides for automatic registration of citizens as voters. According to Art. 8 the voter's electoral address is the address at which his place of residence is registered in accordance with the Law of Ukraine "On Freedom of Movement and Free Choice of Residence in Ukraine", in accordance with Art. 6 of which a citizen of Ukraine, as well as a foreigner or stateless person permanently or temporarily residing in Ukraine, is obliged to register their place of residence within thirty calendar days after withdrawal from registration of residence and arrival at a new place of residence, as a result of which information is entered in the Register of Territorial Communities (Art. 11-2).

A motivated request to change the voting place of a citizen who has the right to vote in the relevant election or referendum, in accordance with the Law of Ukraine "On the State Register of Voters" is possible: 1) without changing the electoral address, ie with the purpose of temporary (for the period of their holding), change of the polling station for the voter, but not later than five days before the day of voting in the respective election or referendum (part 3 of Article 7 of the Law), which does not give the right to vote in local elections at the specified polling station, but only at national elections; 2) with change of the electoral address, the voter who: a) in case of change of his personal data (part 1 of Article 20 of the Law), submits to the body of keeping the Register at the new electoral address an application to which documents (copies of documents) confirming the change of voter's electoral address (Part 2 of Article 20) b) has no registered place of residence (Part 3 of Article 8 of the Law), but appeals with a reasoned request, the acceptance of which gives him the right to exercise active suffrage both in the Ukrainian and local elections.

In the case of a voter's request for a change of election address, the Register authority examines the validity of the application (Part 20 of Article 20 of the Law). The Register authority may check the change of the voter's personal data specified in the application by contacting the relevant bodies, institutions, institutions referred to in Article 22 of this Law.

In accordance with the provisions of Article 8 of the Law of Ukraine "On Ensuring the Rights and Freedoms of Internally Displaced Persons", an internally displaced person (a person who has been forced to leave or abandon their place of residence as a result of or to avoid the negative effects of armed conflict, temporary occupation, pervasive acts of violence, human rights abuses and natural or man-made emergencies) exercises his/her right to vote in elections of the President of Ukraine, Peoples' Deputies of Ukraine, local elections, and referendum by changing the place of voting without changing the election address in accordance with Part 3 of Art. 7 of the Law of Ukraine "On the State Voter Register". However, the fact that without changing the 
election address, the IDP has the right to participate in local elections on an equal footing with other members of the territorial community to which he / she temporarily belongs, has not developed in the provisions of the Law "On Local Elections".

However, Article 3 of the Law of Ukraine "On Local Elections" states that the right to vote in the elections of deputies of village, town, city council, elections of village, town, mayor shall be vested in the citizens of Ukraine who have the right to vote under Article 70 of the Constitution of Ukraine, who belong to the relevant territorial community and reside within the respective constituency. Therefore, the criterion is not so much the electoral address as the belonging to the territorial community.

It is important that the request (application) to change the electoral address should occur exactly to the Register authority at the new electoral address (Part 2 of Article 20 of the Law), similarly, when it comes to changing the polling station. However, the following are of concern: 1) the list of bodies that provide information to the State Voter Register authority does not mention the bodies of income and fees (fiscal bodies) that keep information cards of individuals-taxpayers, containing information about the tax address of citizens and foreigners, which are entered into these cards at the request of such person who can determine as his tax address his place of actual residence or place of residence, which is registered in the State Demographic Register; 2) the question remains: whether for the legislator of Ukraine is sufficient argument for recognition of a person as a member of a territorial community that he has a tax address at his place of actual residence, since according to Article 64 of the Budget Code of Ukraine it is the budget of a territorial community of an administrative-territorial unit, at which the tax address of an individual is recognized, is received in the appropriate share, paid by him/her income tax without the intermediary of the tax agent, which certifies its financial participation in the life of the territorial community and local self-government.

European practitioners solve the problem of exercising active suffrage in the following way: voting by mail (Greece, Belgium, the United Kingdom), proxy voting (Netherlands, France, Belgium), and the most progressive way voting via the Internet (tested in Estonia, Portugal and France) ${ }^{19}$.

Estonia is now the most successful example. In 2000, an electronic identification card was introduced in the country. Every adult of the country has it, like a passport. It allows to control bank accounts, use an electronic signature, file a tax return, pay for transportation services in major cities, travel to EU countries, and more recently participate in elections.

19 Recommendation $\operatorname{Rec}(2006) 6$ of the Committee of Ministers to member states on internally displaced persons. rm.coe.int. Retrieved from https://rm.coe.int/16806b5aaf 
In Ukraine, the law about ID cards has already been adopted and may also become an opportunity to vote in the future.

Thus, in Ukraine there are delimited: Unified demographic register (the register of citizens); registers of territorial communities (places of official registration of a person); Unified voter register; register of taxpayers (tax address of individuals), register of insured persons (individuals who are insured in the system of compulsory state social insurance), register of displaced persons who do not agree among themselves and correction of information in one of them does not cause automatic changes in the in other cases, and in some cases, it is the responsibility of the citizen to apply to make changes to the said resets in case of their change to permanent or temporary residence.

\section{CONCLUSIONS}

Thus, the criterion of payment by the voter of the tax, which in the first stage of the establishment of suffrage played the role of restriction, that is, the tax qualification, became a significant factor (a kind of legal guarantee) of recognition of an individual (first and foremost a citizen, and in some states a foreigner), who has active and passive right to elections of a certain level (local, nationwide, to the EU Parliament). Accordingly, when improving the national electoral legislation, it is necessary to take into account the tax address factor as much as possible when determining the election address of an individual, as well as to take into account the data of the State Register of Individuals of Taxpayers in the automatic and application procedure of the State Register of Voters.

Thus, in the course of establishing the universal suffrage in view of the voter being recognized as a taxpayer in the country of residence, there was: 1) a waiver of the tax qualification; 2) distribution of suffrage, first and foremost, to all citizens regardless of their change to permanent or temporary residence; 3) a recommendation has been introduced, and for EU Member States the obligation to grant voting rights to non-residents who are permanently resident and recognized as residents; 4) removing barriers to the exercise of voter rights and minimizing compulsory registration by filing petitions by persons who has voting rights and are residents, which is facilitated by the practice of establishing a single state register based on the register of taxpayers and insured persons and unification of tax and election addresses of persons with suffrage.

Of course, in every state there is a complex of difficulties of philosophical, political, historical, static, demographic, etc. nature, which leads, first, to civil society disputes about the expediency and timeliness of expanding both the number of persons to whom electoral rights are recognized and the guarantees of such rights, and secondly, to their implementation in law and in practice. However, the European choice of Ukraine necessitates the gradual 
consolidation of the principle of universal suffrage in its modern sense, by means of unification and harmonization of national electoral law with EU law, as well as bringing it into line with international standards, while respecting the interests of the statehood of Ukraine at every step.

\section{SUMMARY}

The article explores the stages of the formation of universal suffrage, namely from the abolition of the tax qualification to the recognition and consolidation of universal and equal suffrage at the constitutional level. The state of recognition of universal suffrage in the sources of international law, European Union legal documents, as well as the experience of legal fixing at the level of laws in a number of countries of the world the right to participate in local elections for foreign residents of the host country are analyzed. The influence of the criterion of foreigners paying taxes to the local budget, recognition of their belonging to the territorial community and the status of the local tax resident on the recognition of their right to participate in local elections are investigated. The state of fulfillment by the European Union Member States of their obligations to ensure that foreigners - tax residents exercise their voting rights in local elections - is highlighted. The problems of realization by the citizens of Ukraine by forced temporary internal migrants of their right to vote in local elections to local self-government bodies of the territorial community of which they are temporary members are investigated. The problematic issues of fixing the voting rights of foreigners - tax residents in local elections in the legislation of Ukraine are covered. It was emphasized that the criterion of payment by the voter of the tax, which in the first stage of election rights played the role of restriction, ie the tax qualification, became a significant factor (a kind of legal guarantee) recognition of an individual (above all a citizen, and in some states a foreigner) as a person who owns active and passive right to elections of a certain level (local, nationwide, to the EU Parliament). Accordingly, in improving the national electoral law, it is necessary to take into account the tax address factor as much as possible when determining the electoral address of an individual, and when forming in the automatic and application procedure of the State Voter Register to take into account the data of the State Register of Individuals Taxpayers.

\section{REFERENCES}

1. Shapoval V.M. (2005) Suchasniy konstitutsionalizm : monogr. [Modern Constitutionalism: monogr.], Kiev: Salkom. 559 p. [in Ukrainian].

2. Carol Berkin The Evolution of Voting Rights (2018). The Gilder Lehrman Institute of American history. www.gilderlehrman.org. Retrieved from https://www.gilderlehrman.org/history-by-era/government-and-civics/ essays/winning-vote-history-voting-rights 
3. Istoriya XIX veka. Konets veka, 1870-1900. (1939) Chast' 1. [History: The Nineteenth Century. End of the Century, 1870-1900. Part 1] / ed. E. Lavisse, A. Pambaud, E. Tarle. Moscow: State Economic and Social Publishing, 340 p. [in Russian].

4. Daniya: analiz izbiratel'nogo zakonodatel'stva v kontekste soblyudeniya obshchedemokraticheskikh standartov i prav cheloveka. (2009) [Denmark: analysis of electoral law in the context of observance of democratic standards and human rights.] Sait of CIS-Europe Monitoring Organization. venice.coe.int. Retrieved from http://www.cis-emo.net/ru/materials/demokraticheskieprocessy/daniya-analiz-izbiratelnogo-zakonodatelstva-v-kontekste-soblyudeniyaobshchedemokraticheskih [in Russian].

5. Martselyak, O.V., Martselyak, S.M. (2015) Pravova pryroda y vydy tsenziv u vyborchomu pravi [Legal nature and types of qualifications in electoral law]. Konstytutsiyno-pravovi akademichni studiyi [Constitutional Law Academic Studies.], № 2, pp. 91-123. [in Ukrainian].

6. Lenher Ya.I. (2016) Vyborchi prava vnutrishn'operemishchenykh osib v Ukrayini: koliziyni pytannya ta mozhlyvi shlyakhy yikh usunennya. [Voting Rights of Internally Displaced Persons in Ukraine: Conflict Issues and Possible Remedies]. Konstytutsiyno-pravovi akademichni studiyi [Constitutional Law Academic Studies], № 1, pp. 19-25 [in Ukrainian].

7. Frants Macher (2004) Dopovid' pro skasuvannya obmezhen' prava holosu na zahal'nykh vyborakh, skhvalena Venetsians'koyu Komisiyeyu (Venetsiya, 3-4 hrudnya 2004 r.). [Franz Macher Report on the Abolition of Restrictions on the Right to Vote in the General Election of, approved by the Venice Commission (Venice, 3-4 December 2004).] Yevropeys'kyy demokratychnyy dorobok $u$ haluzi vyborchoho prava: Materialy Venetsians'koï Komisii, Parlaments'koï Asambleï, Komitetu Ministriv, Konhresu mistsevykh i rehional'nykh vlad Rady Yevropy: per. z anhl. / za red. $Y$ Y.Klyuchkovs'koho. [European democratic achievements in the field of suffrage : Proceedings of the Venice Commission, Parliamentary Assembly, Committee of Ministers, Congress of Local and Regional Authorities of the Council of Europe: trans. from English. / per row Y. Klyuchkovsky, Vyd. 2-e, vypr. i dopovn]. K., 500 p. [in Ukrainian].

8. Recommendation $\operatorname{Rec}(2006) 6$ of the Committee of Ministers to member states on internally displaced persons. rm.coe.int. Retrieved from https://rm.coe.int/16806b5aaf

9. Recommendation 1877 (2009) Parliamentary Assembly "Europe's forgotten people: protecting the human rights of long-term displaced persons". rm.coe.int. Retrieved from http://assembly.coe.int/nw/xml/XRef/XrefXML2HTML-EN.asp?fileid=17759\&lang=en

10. Voting by Nonresidents. (2018) The Gilder Lehrman Institute of American History. 6.20.2018. Retrieved from http://www.ncsl.org/research/ elections-and-campaigns/non-resident-and-non-citizen-voting.aspx 
11. Convention on the Participation of Foreigners in Public Life at Local Level. Strasbourg, Council of Europe 5.II.1992. rm.coe.int. Retrieved from https://rm.coe.int/168007bd26

12. Guidelines on Elections. Adopted by the Venice Commission at its 51st Plenary Session (Venice, 5-6 July 2002). venice.coe.int. Retrieved from https://www.venice.coe.int/webforms/documents/CDL-AD(2002)013-e.aspx

13. Treaty on European Union (Maastricht, 7 February 1992) - Consolidated version 2007. www.cvce.eu. Retrieved from https://www.cvce.eu/en/obj/ treaty_on_european_union_maastricht_7_february_1992_consolidated_version_2 007-en-e92737d6-7557-4ea1-9ca5-123368a7fb88.html

14. Treaty establishing the European Community - part two: citizenship of the Union - article $8 \mathrm{~b} / *$ Codified version of the treaty establishing the European Community. Official Journal. eur-lex.europa.eu. P. 224, 31/08/1992 P. 0011. Retrieved from http://eur-lex.europa.eu/legal-content/RO/TXT/?uri= CELEX:11992E008B

15. Review of Electoral legislation and Practice in OSCE participating states. OSCE, Office for Democratic Institutions and Human Rights (Warsaw, October 15, 2013). www.osce.org. Retrieved from www.osce.org/odihr/ elections $/ 107073$ ?download=true

16. Council Directive 94/80/EC of 19 December 1994 laying down detailed arrangements for the exercise of the right to vote and to stand as a candidate in municipal elections by citizens of the Union residing in a Member State of which they are not nationals. eur-lex.europa.eu. Retrieved from http://eur-lex.europa.eu/legal-content/EN/TXT/HTML/?uri=CELEX: 31994L0080\&from $=\mathrm{EN}$

17. Explanatory report adopted by the Venice Commission at its 52nd Plenary Session (Venice, 18-19 October 2002). Europian commission for democracy through law (Venice commisson). www.venice.coe.int. CDL$\mathrm{AD}(2002) 023$ rev2-cor. P. 14. Retrieved from https://www.venice.coe.int/ webforms/documents/default.aspx?pdffile $=$ CDL-AD(2002)023rev2-cor-e

18. Yevropeys'kyy vyborchyy dorobok [European Electoral Achievement]. CDL (2002) 7 rev (f). www.venice.coe.int. Retrieved from https://www.venice.coe.int/files/CDL-elec-opinions-UKR.pdf [in Ukrainian].

Information about the author: Nataliia Iakymchuk,

Doctor of Science (Law), Professor, Professor at the Department of Financial Law, Law Faculty, Taras Shevchenko National University of Kyiv Kyiv, Ukraine ORCID ID: orcid.org/0000-0002-4848-2323 